<症例報告 $>$

部分脾動脈塞栓療法により汎血球減少のみならず肝機能の

著明な改善をみた非代償性肝硬変の 1 例

$\begin{array}{lllll}\text { 田代 } & \text { 憲司 } & \text { 赤木 公博 } & \text { 東 } & \text { 晃一 } \\ \text { 池田 } & \text { 耕一 } & \text { 野見山賢介 } & \text { 永松 } & \text { 明男* } \\ \text { 崎野 } & \text { 郁夫** } & \text { 藤島 正敏 }{ }^{* * *} & & \end{array}$

要 旨: 症例は 57 歳女性, 肝硬変で外来通院中に肝機能が低下し, 腹水を認めたため入院した。 脾機能立進 (巨大脾腫, 沉血球减少) を伴う非代償性肝硬変と診断し, その治療として部分脾

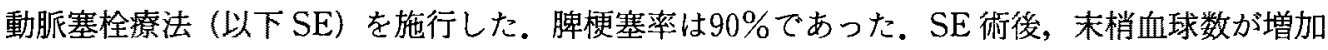
したのみでなく, 肝機能の著明な改善 (Child C から A) が見られ, 術後 1 年半後には, CT 上 で測定された肝容積は術前 $640 \mathrm{~cm}^{3} か ら 780 \mathrm{~cm}^{3} に$ 增加した。また, 術前脾門部の 3 力所に径 $1 \sim 1.5 \mathrm{~cm}$ の脾動脈瘤が認められたが, 術後 3 力月には 2 力所は縮小し, 1 力所は血栓化し消失 した. SE は肝硬変患者の脾機能進による汎血球減少のみでなく, 肝機能の改善が期待される 有用な治療法と考えられる.さらに, 脾動脈瘤の治療としても有用である可能性が示唆された。 索引用語： 部分脾動脈塞栓療法 肝硬変 脾機能元進 脾動脈瘤

\section{はじめに}

肝硬変患者では，脾機能え進によると考えられる汎 血球隇少が見られ ${ }^{1,22}$,特に血小板数の隇少は出血を招 く恐れがあり，肝硬変に合併する肝細胞癌や食道静脈 瘤に対する観血的治療の妨げになることがある．1973 年にSpigos ら゙は，このような脾機能六進を有する肝 硬変患者に対して, partial splenic embolization(SE) を施行し，本法は脾機能六進の一つの治療手段と成り 得ることを報告している．著者らは脾機能立進を伴う 非代償性肝硬変に対して梗塞率が80\%を越える SE を 施行したところ, 汎血球隇少のみでなく, 肝予備能の 著明な改善を見た症例を経験したので，若干の文献的 考察を加えて報告する。

\section{I. 症 例}

患者：57歳，女性。主婦。

主訴：腹水, 下肢の浮腫.

既往歴：26藏時に大量の不整性器出血のため輸血歷 あり。
家族歴・生活歴：特記すべき事項なし.

現病歴：1983年ごろより松㥐感自覚し，その際初 めて肝硬変と診断された，その後外来通院中に，1990 年6月初めより次第に下肢に浮腫が出現し, 腹水, 沉 血球減少を認めるため, 同年 7 月精㚗加療目的で入院 した.

入院時現症：意識清明. 身長 $149 \mathrm{~cm}$, 体重 $55 \mathrm{~kg}$. 脈 拍80/分整, 血圧 $130 / 72 \mathrm{mmHg}$. 胸部には異常を認めな いが，腹部では腹水と胼部におよぶ巨脾を，下肢に浮 腫を認めた。

入院時検查成績 (Table 1): 末梢血液検査にて RBC $275 \times 10^{4} / \mathrm{mm}^{3}$, WBC $1,500 / \mathrm{mm}^{3}$ おょび Plt $1.3 \times 10^{4} / \mathrm{mm}^{3}$ と汎血球減少を認めた。肝機能検查では GOT $64 \mathrm{IU} / \mathrm{L}$, GPT $40 \mathrm{IU} / \mathrm{L}$, T. Bil $2.3 \mathrm{mg} / \mathrm{d} l$, ChE $0.4 \Delta \mathrm{pH}, \mathrm{T}$. Chol $99 \mathrm{mg} / \mathrm{d} l$, Alb $2.9 \mathrm{~g} / \mathrm{d} l$, HPT $33 \%$, $\mathrm{ICG}_{\mathrm{R} 15} 45.1 \%$ であった. HCV-Ab(I)は陽性, PA-IgG $2,051 \mathrm{ng} / 10^{7}$ cells と高値を示した。

肝シンチグラム (Fig. 1A) では肝は右葉を中心に高

Kenji Tashiro, Kimihiro Akagi, Kouichi Azuma, Kouichi Ikeda, Kensuke NomiYama*, Ikuo Sakino** and Masatoshi FujISHIMA***

"済生会八幡総合病院内科, **同 放射線科, ***九州大学第 2 内科

<受付日1996年 2 月 2 日 $>$ 
Table 1 Laboratory data on admission

\begin{tabular}{|c|c|c|c|}
\hline \multicolumn{2}{|c|}{ Urinalysis: } & $\gamma \cdot \mathrm{GTP}$ & $14 \mathrm{IU} / \mathrm{L}$ \\
\hline Prot & $(-)$ & T.Bil & $2.3 \mathrm{mg} / \mathrm{d} l$ \\
\hline Suger & $(-)$ & D.Bil & $1.0 \mathrm{mg} / \mathrm{d} l$ \\
\hline O.B. & $(-)$ & T.Chol & $99 \mathrm{mg} / \mathrm{d} l$ \\
\hline Stool: 0 & $(-)$ & T.P & $6.5 \mathrm{~g} / \mathrm{d} l$ \\
\hline \multicolumn{2}{|c|}{ CBC \& coagulation : } & Alb & $2.9 \mathrm{~g} / \mathrm{d} l$ \\
\hline WBC & $1.500 \mathrm{~mm}^{3}$ & $\gamma \cdot \mathrm{glb}$ & $38.7 \%$ \\
\hline $\mathrm{RBC}$ & $275 \times 10^{4} \mathrm{~mm}^{3}$ & $\mathrm{NH}_{3}$ & $32 \mu \mathrm{g} / \mathrm{d} l$ \\
\hline $\mathrm{Hb}$ & $10.0 \mathrm{~g} / \mathrm{d} l$ & $\mathrm{ICG}_{\mathrm{RIS}}$ & $45.1 \%$ \\
\hline $\mathrm{Ht}$ & $28.3 \%$ & \multicolumn{2}{|c|}{ PAIgG $2.051 \mathrm{ng} / 10^{7}$ cells } \\
\hline Plt & $1.3 \times 10^{4} / \mathrm{mm}^{3}$ & PBIgG & $(-)$ \\
\hline BI.T & $5^{\prime} 30^{\prime \prime}$ & Serology : & \\
\hline HPT & $33 \%$ & HBsAg & $(-)$ \\
\hline $\mathrm{PT}$ & $29 \%$ & $\mathrm{HBsAb}$ & $(+)$ \\
\hline \multicolumn{2}{|c|}{ Blood chemistory : } & HCVAb(1) & $(+)$ \\
\hline GOT & $64 \mathrm{IU} / \mathrm{L}$ & RA & $(+)$ \\
\hline GPT & $40 \mathrm{IU} / \mathrm{L}$ & ANF & $(-)$ \\
\hline $\mathrm{LDH}$ & $358 \mathrm{IU} / \mathrm{L}$ & ASMA & $40 x$ \\
\hline
\end{tabular}

度の萎縮を示し, 巨脾を認めた。

腹腔動脈造影（Fig. 2A）：Seldinger 法により大腿 動脈からカテーテルを腹腔動脈に挿入し，血管造影を した. 脾動脈の拡張, 蛇行と径 1 ～ $1.5 \mathrm{~cm}$ の脾動脈瘤を 3 力所に認めた。

SE：腹腔動脈造影後,カテーテルを選択的に脾動脈 の脺尾動脈分岐より遠位側まで挿入し，脾動脈造影に 引き続き，抗生剤を混ぜた gelatin sponge にて $80 \% を$

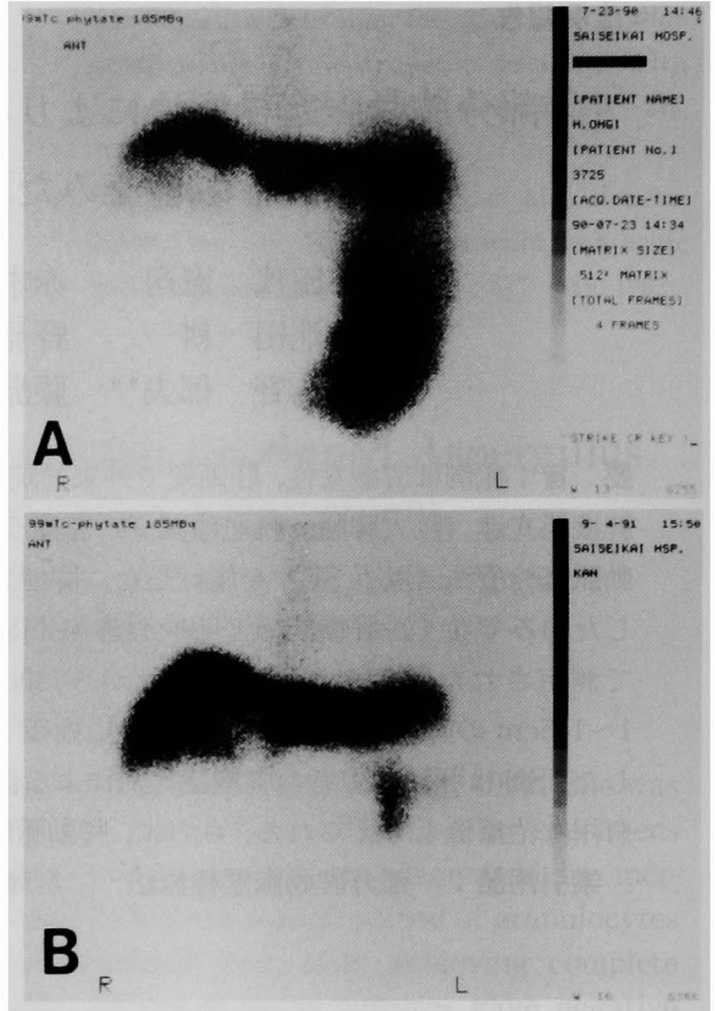

Fig. $1{ }^{99 m}$ Tc scintigrams (A) before and (B) 13 months after SE. Splenomegaly markedly reduced and RI-uptake in the liver increased after $\mathrm{SE}$.

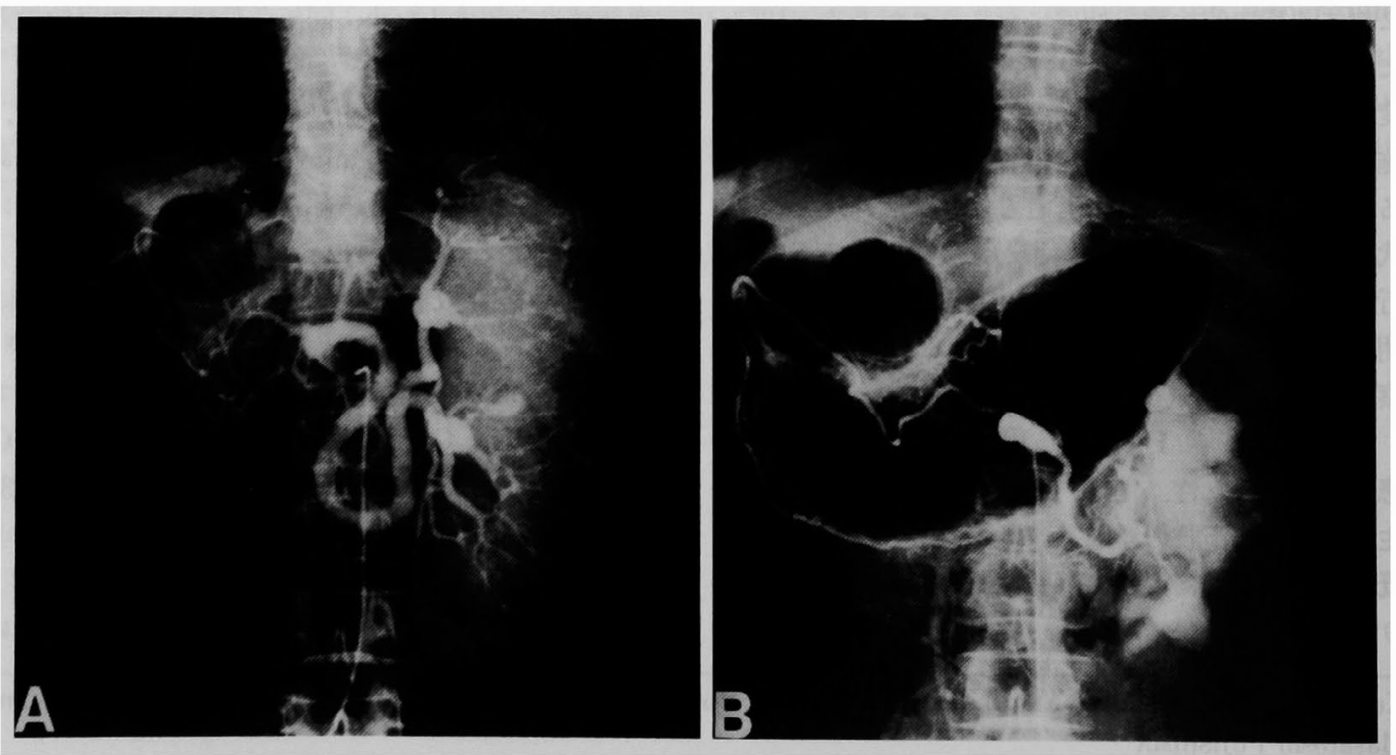

Fig. 2 Angiographies of the splenic artery (A) before and (B) 2.5 months after SE. Dilataion and three aneurysms of splenic artery shrank or disapeared after SE. 
目標として脾塞拴術を施行した，梗塞率は90\%であっ た.

臨床経過（Fig. 3, Table 2)：本症例は沉血球減少 を伴うChild Cの肝硬変であり，まず腹水のコント ロールをした後に, SEを施行した。術後 1 週間で末梢 血球数は增加し，PA-IgG 值の低下が見られた，その
後，血球数は正常化した， $\gamma$-glob，ICG 值は術後一過 性に増悪し, 以後改善は途延したが(Fig. 3)，T. Chol, Alb, ChE，HPT 值は著明に改善した(Fig. 3). SE 施 行直後に発熱, 左側腹部痛, 腹水の増加などが見られ た.しかし，いずれも一時的て対症療法にて改善した。 術後2.5力月に施行した腹腔動脈造影では脾動脈の径
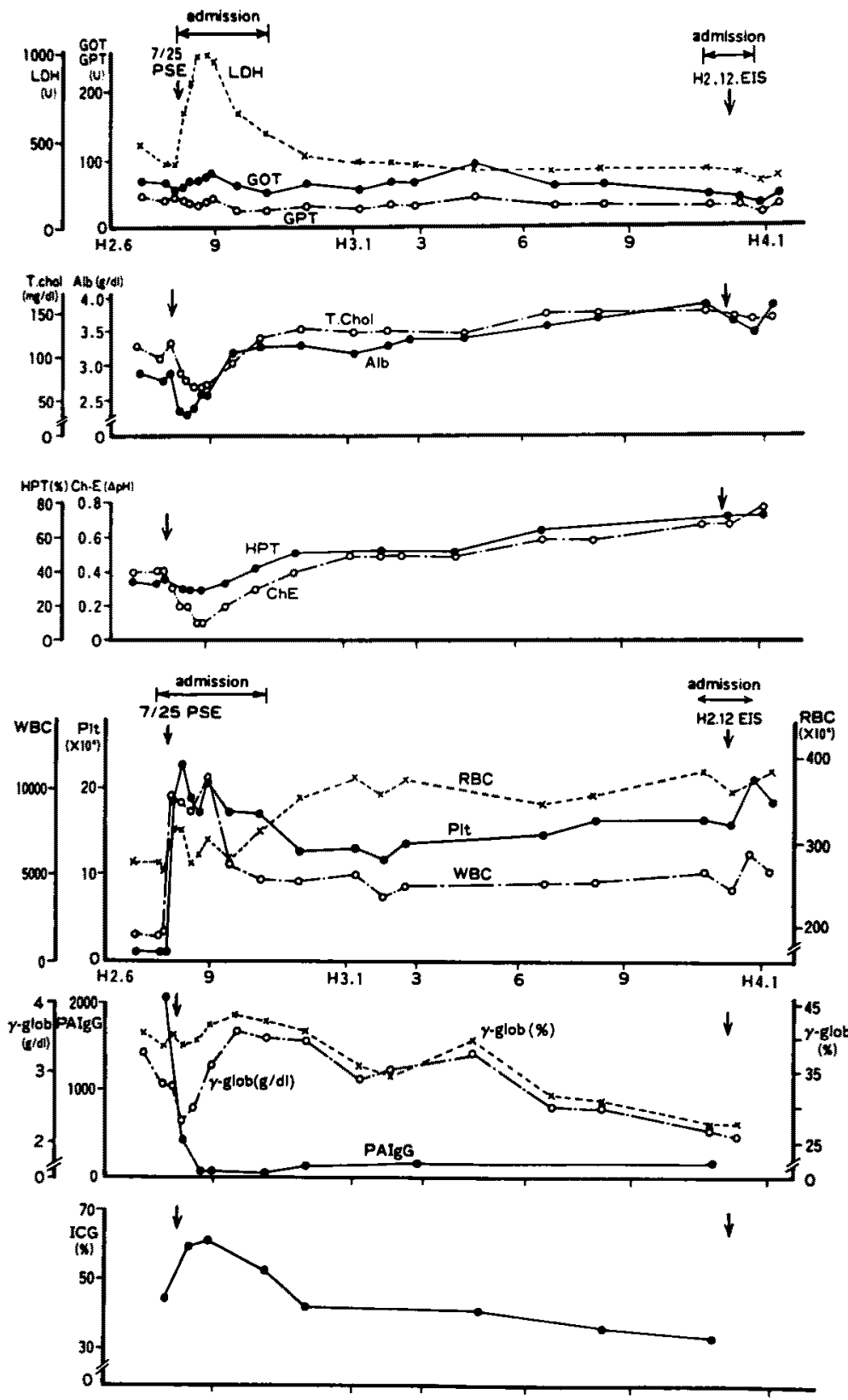

Fig. 3 Clinical course of the patient. 
Table 2 Changes in laboratory data before and after partial splenic embolization (SE).

\begin{tabular}{|c|c|c|c|c|c|}
\hline \multirow{2}{*}{\multicolumn{2}{|c|}{$\mathrm{SE}$}} & \multirow{2}{*}{ before } & \multicolumn{3}{|c|}{ after (years) } \\
\hline & & & 1.5 & 3 & 5 \\
\hline WBC & $/ \mathrm{mm}^{3}$ & 1,800 & 5,200 & 4,200 & 4,400 \\
\hline $\mathrm{RBC} \times 10^{4}$ & $/ \mathrm{mm}^{3}$ & 268 & 381 & 372 & 375 \\
\hline Pit $\times 10^{4}$ & $/ \mathrm{mm}^{3}$ & 1.4 & 18.6 & 14.9 & 14.9 \\
\hline HPT & $\%$ & 38 & 76 & 80 & 70 \\
\hline GOT & $\mathrm{IU} / \mathrm{L}$ & 55 & 45 & 55 & 88 \\
\hline GOT & $\mathrm{IU} / \mathrm{L}$ & 43 & 30 & 40 & 63 \\
\hline T.Bil & $\mathrm{mg} / \mathrm{d} l$ & 2.3 & 1.1 & 0.9 & 1.4 \\
\hline ChE & $\Delta \mathrm{pH}$ & 0.4 & 0.8 & 0.8 & 0.7 \\
\hline T.Chol & $\mathrm{mg} / \mathrm{d} l$ & 118 & 144 & 153 & 167 \\
\hline Alb & $\mathrm{g} / \mathrm{d} l$ & 2.9 & 3.9 & 4.1 & 4.0 \\
\hline$\gamma \cdot \mathrm{glb}$ & $\%$ & 40.2 & 27.8 & 24.9 & 27.7 \\
\hline PAIgG* & & $2,051.2$ & 198.2 & 133.6 & 86.2 \\
\hline $\mathrm{ICG}_{\mathrm{R} 15}$ & $\%$ & 45.1 & 35.2 & 25.0 & 40.8 \\
\hline Volume** & $\mathrm{cm}^{3}$ & 640 & 780 & - & - \\
\hline
\end{tabular}

•Platelt associated $\mathrm{IgG} ; \mathrm{ng} / 10^{7}$ cell.

* Liver volume was calculated on $\mathrm{CT}^{*}$.

は縮小し (Fig. 2B), 脾門部に見られた脾動脈瘤は 1 力所は完全に血栓化し，残りの 2 力所も縮小化した (Fig. 2B). 静脈相では脾静脈および門脈血流量が著 明に減少した (Fig. 4A，B). 上腸管膜造影では術後に 門脈径の縮小化は見られないが，血流量の増加傾向を 認めた (Fig. 5A，B).SE 前後で肝シンチグラムを比
較すると，脾臓は著明に縮小した（Fig. 1B)。また， $\mathrm{CT}$ 検査にて術後1.5年に肝右葉前区域および 5 年後 に肝左葉外側域の再生が認められ (Fig. 6A〜D), SE 前と 1.5 年後の肝容積 ${ }^{4}$ を測定すると術前 $640 \mathrm{~cm}^{3}$, 術後 $780 \mathrm{~cm}^{3}$ であり, 術後に明らかな肝容積の増加を認めた (Table 2).また, CT 上で閏脈径の変化を経年的に見 ると，著明な縮小化を認めた(Fig. $6 \mathrm{~A} \sim \mathrm{D})$. 肝予備能 も Child C から Child A k改善し，その改善は少なく とも術後 5 年間持続して見られた（Table 2).

\section{II. 考 察}

肝硬変患者ではその程度に差はあるものの脾機能六 進が見られる. しかし, 肝硬変末期に出現する腹水, 肝性脳症, 門脈圧立進に対する治療はなされても,こ の脾機能六進に対しては治療されないまま放置されて いることが多い.このような脾機能六進を有する肝硬 変症例に対して, 1973年 Maddison'占が初めて脾動脈支 配の全領域を塞栓する脾動脈塞栓療法を行ったが, 重 篤な合併症のため臨床応用には至らなかった。 その後, 1979年に Spigos ら ${ }^{3} か ゙$ gelatin sponge 細片を用いて 部分的に脾動脈領域を塞栓する SE を考案し, 比較的 安全に脾機能六進の治療が可能となった．本法が摘脾 より優れている点としては，脾臓の一部を残すためそ の免疫能を温存することができること，および繰り返 し行って梗塞率を調節できる点などが挙げられる.SE の梗塞率について Spigos ら゙は実験動物で免疫能に
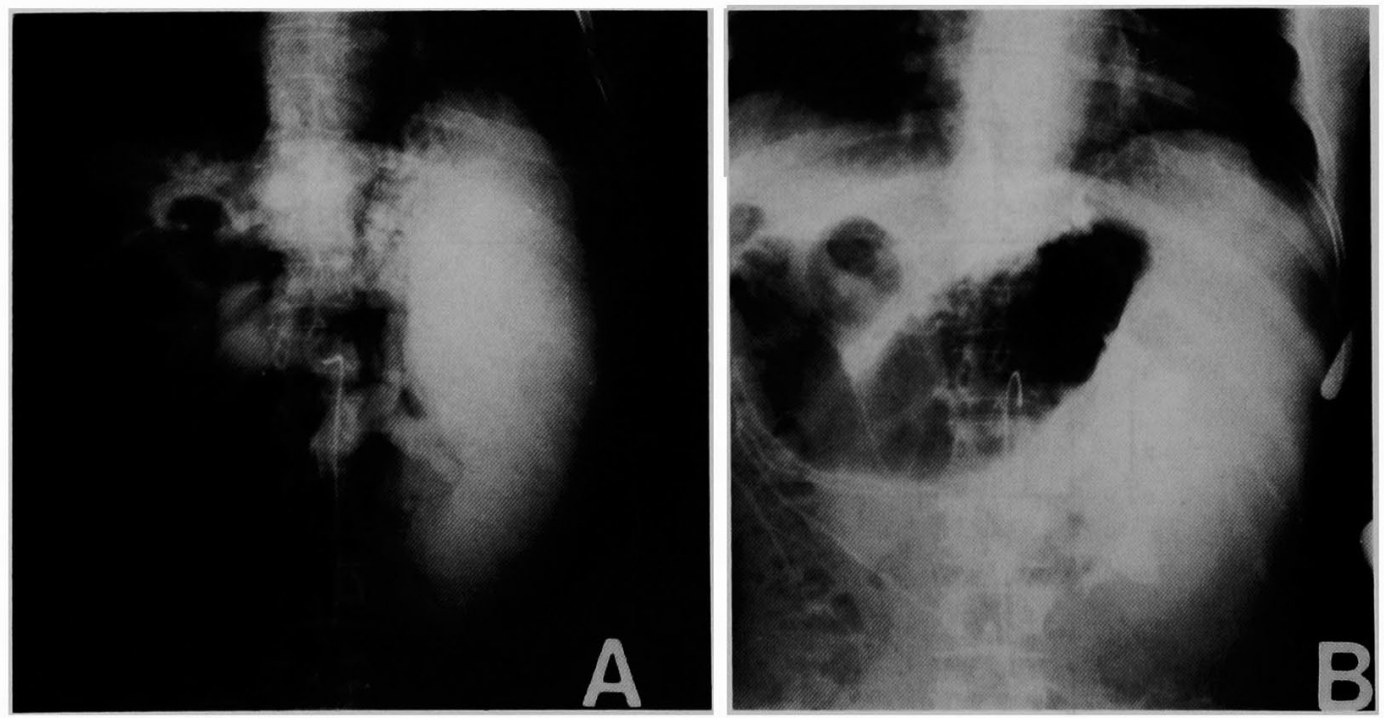

Fig. 4 Portographies through celiac angiography (A) before and (B) 2.5 months after SE. Portal flow from splenic vein was markedly decreased after SE. 

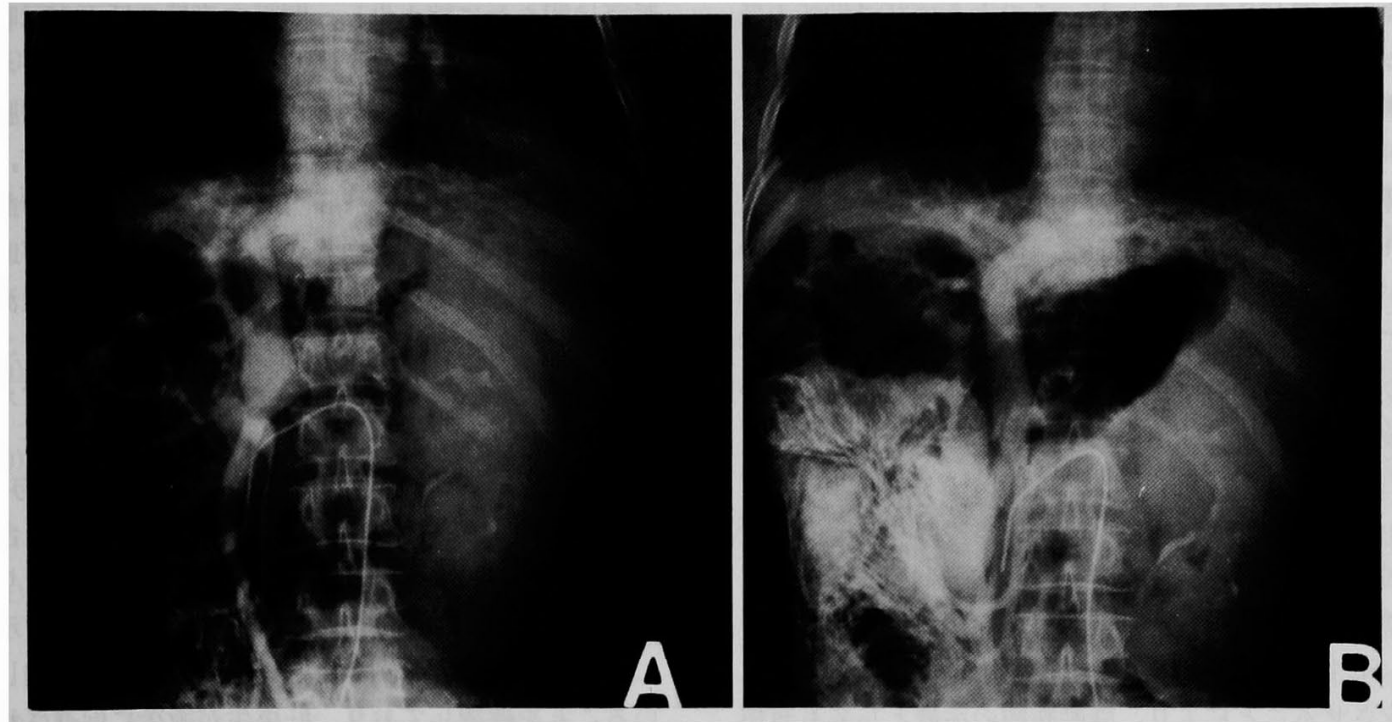

Fig. 5 Portographies through superior mesenteric angiography (A) before and (B) 2.5 months after SE. Portal flow seems to be slightly incresed after SE.

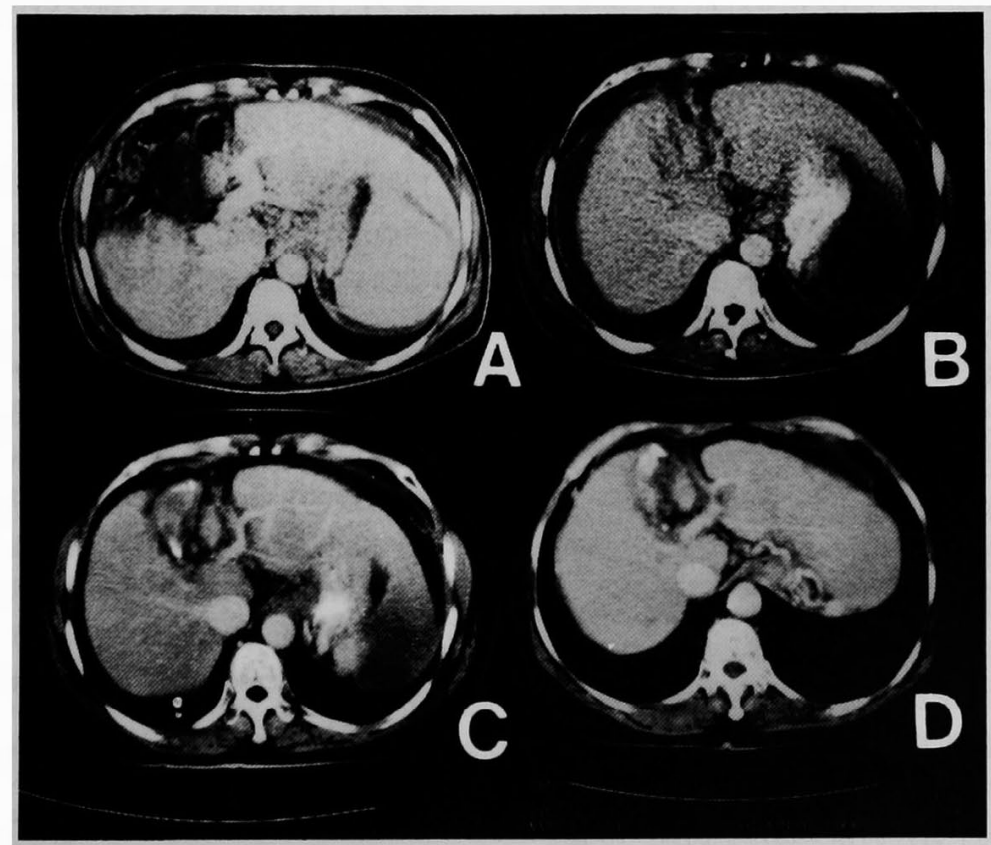

Fig. 6 Computed tomographies (A) before and (B) 1.5, (C) 3 and (D) 5 years after SE. Portal vein was markedly reduced in size after SE, and liver volumes were increased at anterior segment of right lobe (B-D) and lateral segment of left lobe (D) after SE.

与える影響が少ないのは50〜70\%であり，80\%を越す と脾破裂，肝膿瘍などの合併症の頻度が增加したと報 告した. しかし，脾機能六進を有する肝硬変を治療す
る場合には，80\%を目標とした SE が必要であると考 えられる゙．著者らが今回経験した症例では初回梗塞 率が90\%で，肝不全がより進行する結果となり，その 
ための治療が必要であった。このように肝予備能の低 下したChild C症例にSE を行う場合にも，広範囲の 梗塞が必要であるが，一度に梗塞せずに，分けて行う 方が合併症も少なく管理も容易であると思われた。

脾機能六進は肝硬変に伴う門脈圧六進が一因と考え られる. 本症では脾動脈血流量が増加するために血管 壁が拡張し，障害され，脾動脈溜を見ることが報告さ れている ${ }^{7.8)}$. 著者らの症例でも血管造影で脾動脈瘤が 3 力所に誌められた。本症の合併症の一つに動脈瘤の 破裂があり，致死的出血をきたすことがあるため，そ の治療として動脈溜とともに摘脾がなされている8 しかし，症例は非代償性肝硬変患者であり，その手術 に耐えられない可能性を考え，SE を施行した，術後, 脾動脈の径は縮小し, 動脈溜は血栓化および縮小化し た. SE はその梗塞率が高い場合には, 脾動脈血流量を 減少させることにより，脾動脈瘤の治療としても有用 であると考えられた。

本症例の SEの梗塞率は $90 \%$ で, 術後にWBC は $1,880 / \mathrm{mm}^{3}$ から $5.200 / \mathrm{mm}^{3}$ に, Plt も1.4 $1.10^{4} / \mathrm{mm}^{3}$ か $518.6 \times 10^{4} / \mathrm{mm}^{3}$ に堌加し, Alb 值は $2.9 \mathrm{~g} / \mathrm{d} l$ から 3.9 $\mathrm{g} / \mathrm{d} l$, 肝機能恃 Child C から $\mathrm{A}$ へと著明に改善し，そ の効果は SE 後 5 年間以上持続して見られた。このよ うな臨床経過から，SE 注肝硬変患者において脾機能 六進状態を治療するのみでなく, 何らかの機序により 肝予備能をも改善するものと考えられる.SE後に血 小板数の增加のみでなく, 肝機能の改善をみたとする 報告6,10-13) が見られるが、肝容積の変化を測定した例 は見られない.CT上で肝の面積を測定し，それらに断 面積間の距離をかけ，積分して得られた肝の体積“が, 本症例では22\%增加した。この変化は肝硬変の自然経 過というより, SEによるもので, 術後に肝再生が見ら れたものと思方れる。

$\mathrm{SE}$ 後に見られる肝機能の改善機序に関して, Porter ら ${ }^{14 /}$ は脾動脈血流量が減少し, 相対的に肝動脈およ び上腸管膜動脈の血流量が増加することを認めてお り, Hirai ら"'はこの肝血行動態の変化が肝機能の改 善に関与しているのではないかと述へている.一方, 橋口ら ${ }^{(5)}$ は超音波ドブラー法を用いて聞脈本幹および 脾門部で血流量を測定し, SE 1 力月後に脾静脈血流 量は有意に低下し，その結果門脈血流量が約 $18 \%$ 低下 することを報告している、本症例でも術後 $2.5 力 月 に$ 施 行された血管造影で脾動脈を介する門脈血流は著明に 減少し，相対的に上晹管膜動脈を介する門脈血流はや や增加する傾向が見られたが，その後のCTでは，門
脈径は明らかに縮小化し, 門脈血流量の低下が示唆さ れた。また, ICG 値は一時悪化し, 肝機能のマーカー より遅れて改善しており，ICG 值はSEによる門脈血 流の低下を反映しているものと考光られた。一方，梅 原ら ${ }^{11}$ は肝硬変患者では肝内血管抵抗の上昇と脾血流 増加のために肝の組織血流がうっ滞し, 肝障害が助長 されていると考え, 門脈血の一部である脾静脈血流を SEにより減少させ, 肝臟のうっ血を改善させること が, 術後の肝機能の改善に関与しているものと考えて いる.

谷浦ら ${ }^{16)}$ は, 摘脾したラットに四塩化炭素を投与し， 摘脾をしなかった対照ラットに比し肝臓の DNA 合成 の促進が見られたと報告している．彼らは脾臟より何 らかの肝再生抑制物質が産生されている可能性を示唆 している. 我々の症例では SE 後に肝容積が増加して いることを確認しており, 肝再生が術後に促進され, その結果肝機能が改善したものと考えられた.しかし， この肝再生を促進または㧕制する因子については不明 であり, 今後 SE 前後で各種の cytokine などがどのよ うに変化し, 肝細胞機能および肝再生に関与している かについて解明して行く必要があると思われる.

結語

巨脾を有する非代償性肝硬変患者に SEを施行し， 末梢血球数の増加だけでなく肝予備能の改善, 肝容積 の增加を認めた症例を経験したので報告した。

\section{文献}

1) Aster RH : Pooling of platelets in the spleen: Role in the pathogenesis of "hypersplenic" thrombocytopenia. J Clin Invest $45: 645-657$, 1966

2) Kajiwara E, Akagi K, Azuma K, Onoyama K, Fujishima $M$ : Evidence for an immunological pathogenesis of thrombocytopenia in chronic liver disease. Am J Gastroenterol 90 : 962-966, 1995

3) Spigos D, Jonasson O, Mozes M, et al : Partial splenic embolization in treatment of hypersplenism. Am J Roentgenol 13: 777-782, 1979

4）森山紀之：肝切除に伴う残肝体積の変化.「肝 CT 読影の実際」市川平三郎，山田達哉編. 金原出版 株式会社, 東京, 1987, p157

5) Maddison E: Embolic therapy of hypersplenism. Invest Radiol 8: 280-281, 1973

6）池田耕一, 赤木公博, 崎野有夫, 他 : 肝硬変㭧者に おける部分脾動脈塞栓療法の効果について。肝臓 
$33(2): 83,1992$

7) Itzchak $Y$, Dorfman G, Pingoud E: Relationship of pressure and flow to arterial diameter. Invest Radiol 17 : 265-270, 1982

8) Ohta $M$, Hashizume $M$, Ueno $K$, et al: Hemodynamic study of splenic artery aneurysm in portal hypertensin. HepatoGastroenterol $41: 181-184,1994$

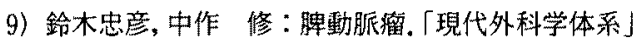
木本誠二 編. 中山書店, 東京, $1968,39, \mathrm{p} 222-223$

10）田尻 孝, 梅原松臣, 滰, 他：外科領域にお ける肝硬㚆症の病態に対する塞栓療法の意義.日 外会誌 $9: 1227-1230,1985$

11）梅原松臣, 田层 孝, 渡辺 章, 他: 門脈圧方進症 に対する選択的脾動脈塞栓術の意義. 日消外会誌 19: 1639-1645, 1986

12) Hirai $K$, Kawazoe $Y$, Yamashita $K$, et al: Transcatheter partial splenic arterial emboliza- tion in patients with hypersplenism : A clinical evaluation as supporting therapy for hepatocellular carcinoma and liver cirrhosis. HepatoGastroenterol 33: 105-108, 1986

13）野見山賢介, 赤木公博, 渡辺英則, 他: 肝硬変患者 における部分脾動脈塞栓療法の肝機能に及ほす影 響について。福岡医誌 $82: 105-109,1991$

14) Porter B, Frey C, Link D, et al: Splenic embolization method by the video dilution technique. Am J Roentgenol 141: 1063-1065, 1983

15）橋口衛,鈴木統久,野見山賢介，他：肝硬变患者 における部分脾動脈塞程療法による肝血行動態の 変化と肝予備能の変化について. 日消会誌 92 ： 1590,1995

16）谷浦 笈，山下隆史，橋本 仁，他：肝再生におよ ほす脾の影響に関する実験的研究。肝缄 $24: 335$ ， 1983

\title{
Efficasy of partial splenic embolization for the treatment of liver cirrhosis with hypersplenism: A case report
}

\author{
Kenji Tashiro, Kimihiro AKagi, Kouichi Azuma, Kouichi Ikeda, \\ Kensuke NomiYania*, Ikuo SAKINO** \\ and Masatoshi FujISHIMA***
}

A 57-year-old woman with decompenzated liver cirrhosis was admitted to our hospital. She had severe hypersplenism with marked splenomegaly and pancytopenia. We performed partial splenic embolization (SE) with a $90 \%$ infarction rate. The SE treatment led not only to a sustained increase in both platelet and white blood cell counts but also to a great improvement of hepatic function (Child $\mathrm{C}$ to $\mathrm{A}$ ). In addition, liver volume increased from $640 \mathrm{~cm}^{3}$ before $\mathrm{SE}$ to $780 \mathrm{~cm}^{3}$ at 1.5 years after SE, while 3 aneurysms of splenic artery shrank or disappered after SE. These findings may suggest that SE performed with a high infarction rate of the spleen is a useful therapy for liver cirrhosis with hypersplenism.

* Department of Internal Medicine, Saiseikai Yahata General Hospital (Kitakyushyu)

** Department of Radiology, Saiseikai Yahata General Hospital (Kitakyushyu)

*** Second Department of Internal Medicine, Faculty of Medicine, Kyushyu University (Fukuoka) 